\title{
Regional differentiation of electricity prices: social-equitable approach
}

\author{
Grzegorz Mentel
}

Rzeszow Univeristy of Technology,

Al. Powstańców Warszawy 12, 35-959 Rzeszow, Poland

Email: gmentel@prz.edu.pl

\section{Tetiana Vasilyeva*, Yaryna Samusevych and Svitlana Pryymenko}

\author{
Sumy State University, \\ Rimskogo-Korsakova str. 2, Sumy, Ukraine \\ Email: tavasilyeva@fem.sumdu.edu.ua \\ Email: y.samusevych@uabs.sumdu.edu.ua \\ Email: Svetlanapologiy1987@gmail.com \\ *Corresponding author
}

\begin{abstract}
Based on the principle of social equitability and the concept of green energy, a new approach to electricity pricing on local level has been developed. The balance of electricity production and its consumption by the population of a certain territory, the volumes of direct and indirect hazardous substances emissions from the energy sector and the structure of the energy capacities of the region are the main factors determining the electricity pricing at the regional level. The calculations were carried out on the statistical data of 22 regions of Ukraine up to 2016. It is proposed to implement regional differentiation of retail tariffs for electricity. It is advisable to apply a reduction in fixed tariffs for electricity in 13 regions of Ukraine where the largest energy capacities concentrated. The increase in the electricity tariff is expected to be carried out in nine regions that do not meet the needs of the population with the help of energy of own production. The use of correction factors provides for the formation of long-term incentives for switching to the production of green energy both in regions that have a deficit and an excess of energy capacity.
\end{abstract}

Keywords: electricity pricing; regional tariff; carbon emissions; energy consumption; social equitability.

Reference to this paper should be made as follows: Mentel, G., Vasilyeva, T., Samusevych, Y. and Pryymenko, S. (2018) 'Regional differentiation of electricity prices: social-equitable approach', Int. J. Environmental Technology and Management, Vol. 21, Nos. 5/6, pp.354-372.

Biographical notes: Grzegorz Mentel already completed his $\mathrm{PhD}$. He worked at the Rzeszow University of Technology, Faculty of Management at the Department of Quantitative Methods in 2000. He also worked as a Lecturer in 2007. In 2010-2012, he is a Branch Manager of the Bank Pocztowy S.A. in Rzeszow. He was the author of publications in the field of finance and capital markets, including monographs about the risk of financial instruments. He specialises in risk management of securities, fundamental analysis, technical analysis, multivariate analysis and forecasting. 
Tetiana Vasilyeva is the Director of Oleg Balatskyi Academic and Research Institute of Finance, Economics and Management at the Sumy State University, Ukraine. She received her Scientific in Economics in 2008. She has published more than 150 scientific papers, including 28 papers in international peer-reviewed journals. He is a leader of four and a contributor of more than ten scientific and research projects, including international ones. The sphere of her scientific interests includes investment and innovations, sustainable development, social responsibility, and risk-management.

Yaryna Samusevych is a Senior Lecturer of Accounting and Taxation Department at the Sumy State University. In 2016, she received her Scientific of $\mathrm{PhD}$ in Economics. She has published more than 20 scientific papers, including three papers in international peer-reviewed journals. She is a contributor of one scientific and research project. The sphere of her scientific interests includes fiscal policy, financial regulation, and environmental economics.

Svitlana Pryymenko is an assistant of Senior Lecturer in the Public Health Department at the Sumy State University. In 2015, she received her Scientific of $\mathrm{PhD}$ in Economics. She is an author of about 20 scientific papers, including two papers in international peer-reviewed journals. The sphere of her scientific interests includes energy security, sustainable development, and environmental economics.

\section{Introduction}

Over the past decades because of global environmental, energy and economic crises, the level of development of the fuel and energy complex has become one of the dominant factors determining the level of national security, the country's competitiveness in the world market and its economic stability. In the 1980-1990s the energy crisis has changed for the environmental one, so special attention has been paid to solving environmental problems related to energy.

As the analysis has shown, over the past decades, energy has become the main source (about 40\%) of carbon emissions into the atmosphere, and in 1971-2014 these emissions increased by $170 \%$. In 2013, Ukraine took the sixth place after Germany, Britain, Italy, France and Poland for $\mathrm{CO}_{2}$ emissions into the atmosphere. The source of $51 \%$ of these emissions are coal-fired power plants, $26 \%$ power plants running on gas. For comparison, nuclear power plants are the source of only $1 \%$ of these emissions, hydroelectric power plants $-9 \%$, solar power stations $-11 \%$, wind power stations $-2 \%$.

At the same time, thermal power plants are the largest electric power producers, they use fossil fuels as energy sources. These kinds of fuel provide $80 \%$ of the world demand for energy annually (International Energy Agency, 2014). That is why the efforts of most countries are aimed at reducing the share of electricity, the production of which is associated with significant emissions of pollutants.

Piłatowska and Włodarczyk (2018) conducted the study that shows that despite the trend to energy intensity reduction and increase in the share of energy derived from renewable sources, there is still a stable long-term relationship between GDP growth and increased carbon emissions in most European countries. On the other hand, the 
relationship between the value added created in the energy sector and GDP growth is weak (Mačerinskienè and Kremer-Matyškevič, 2017; Kasperowicz and Štreimikienè, 2016), which indicates the feasibility of reforming it in the direction of production increase of clean electricity.

As of 2005 the share of electricity consumed from alternative sources in the countries of the European Union was from 1 to $40 \%$ of gross consumption. At the same time, countries have set targets to increase this share until 2020. The minimum share of electricity consumption planned by the EU countries in 2020 should reach $10 \%$ of the total production. On the other hand, countries that have already made significant progress in the production and consumption of environmentally safe electricity have planned to increase their share of consumption to $49 \%$ (Sweden), 40\% (Latvia), 38\% (Finland), 35\% (Austria) by 2020 and already in 2008 the share of electricity consumed from alternative sources in Finland exceeded 30\%, it was about $41 \%$ in Latvia, 55\% in Sweden, over $60 \%$ in Austria (Ruska and Kiviluoma, 2008).

The transition of Ukraine to the concept of green energy is accompanied by a few problems, most of which are of a financial nature (investments in new technologies) or are caused by the social interest of the population. Vasilyeva and Kasyanenko (2013) argue that the most influential factor in the innovative potential of Ukrainian national economy is the financial component, therefore, the stimulation of structural changes in the energy sector of Ukraine should be performed through the financial leverage. This conclusion is supported by Sotnyk (2016) who points out the necessity of financial assistance to energy efficiency infrastruction development in Ukraine. At the same time, restructuring the national economy in line with European trends should include an improvement in the environment protection and reservation (Pilia, 2018).

Considering the fact that in developing countries corruption remains a significant factor restraining investment processes, macroeconomic stability (Nguedie, 2018; Yevdokimov et al., 2018), and direct government spending on supporting the economy does not create long-term incentives for economic growth (Kouassi, 2018; Vasilyeva et al., 2018b), it is advisable to restructure the energy sector creating financial conditions in which the electricity production from sources increasing the pollution of the environment makes no economic sense.

Despite direct subsidisation of renewable energy production in Germany, the increase in renewable energy leads to significant electricity price rising - more than $70 \%$ during 2005-2014 (Bryce, 2016; Balitskiy et al., 2016). The increase in electricity prices is also characteristic of other European countries that have adopted a policy for renewable energy support (Spain, UK, Denmark, Italy and other).

Today, Ukrainian heat and power companies do not have significant incentives to reduce emissions of harmful substances. The existing pricing system does not stimulate the company to environmental actions, therefore, a new approach is needed to reduce specific fuel consumption, losses in networks, as well as to reduce emissions of harmful substances.

Government initiatives to improve energy efficiency should be accompanied by a simultaneous increase in fees for carbon emissions and to restrain the demand for energy consumption. If the state does not take active measures towards energy efficiency, then the demand for electricity will increase, and the level of $\mathrm{CO}_{2}$ emissions will exceed the average (reference) value.

Significant disproportions in the location of power plants capacities in Ukraine, a small part of the territories of nature protection, recreational, health, historical and 
cultural destination are the reasons for the formation of excessive man-caused stress on the natural environment and a high degree of contamination.

One of the problems confirms the need to apply incentives to reform the current structure of electricity production in Ukraine, as well as a high level of environmental and economic dependence of the energy sector. According to Vasilyeva and Pryymenko (2014), traditional fuel types (petroleum, gas, coal, oil), which are used by most power plants, have a level of ecological and economic dependence, exceeding $60 \%$. On the other hand, 16 of 25 regions of Ukraine have a significant potential for biofuels, biomass and waste, the level of energy dependence for which does not exceed $50 \%$. Thus, the authors in the paper (Cebula and Pimonenko, 2015) proved that Ukraine had the huge potential as an agricultural country to develop biogas compare with other alternative resources.

At the same time, the natural potential of Ukraine creates ample opportunities for the construction of new power plants operating on renewable energy sources. However, this direction of investment is economically advantageous, since the estimated payback period for small hydroelectric power plants is about two years, for wind power plants -2.6 years, and solar power stations -4 years (Kharlamova et al., 2016).

The first steps towards the implementation of the concept of green energy in Ukraine should be considered the elimination of existing disproportions in the levels of social and economic development of the country's territory. Ukrainian Polissia, Vinnytsia, Kirovograd, Poltava, Sumy, Kharkiv, Cherkassy regions, and some districts of Dnipropetrovsk and Zaporizhzhya regions belong to Ukrainian regions with a lower than average level of development balance. The Transcarpathia, Ivano-Frankivsk, Lviv and Odessa regions belong to the regions of Ukraine with an above-average level of development.

The unevenness of the location of power capacity in Ukrainian regions can be the reason for the growth of social tension. Thus, in 7 of 22 regions of Ukraine, the number of people living in the hazard area of thermal power plants comprises from 13 to more than 300 thousand people, and these regions are responsible for the production of most electricity in the country.

Negative implications of electricity production on people health are confirmed by scientific research. Thus, Wang and Orris (2015) define health risks of electricity production not only concerning for the fossil fuels energy, but even for renewable energy production. According to Dudnyk and Koshelia (2015) health state of population living in the regions of Ukraine with high concentration of electricity production is characterised by higher level of morbidity in comparison of other regions.

Considering all the above, regional disproportions in electricity production and consumption, the bulk of the heat energy and the lack of compensation mechanisms for harmful anthropogenic impact on the population living in power plant locations are the main problems of the energy sector in Ukraine. Current tools for stimulating environmental activities at the regional level in Ukraine are not effective, while active implementation of measures to greening the regions' economies is a prerequisite for an effective implementation of their financial capacity (Vysochyna et al., 2015; Chygryn, 2016; Sotnyk and Kulyk, 2014).

Sustainable development of Ukrainian energy sector provides for a balance between three interrelated components: economic feasibility, environmental impact and social consequences. Therefore, any actions aimed at changing the current situation should 
solve the problem that has developed in the complex of cause and effect relations, when inadequate economic efficiency leads to an increase in environmental pollution resulting in a violation of social development.

An important stage in the procedure for reforming the energy sector should be the search for effective economic levers of influence, capable, on the one hand, of restraining the level of technogenic load from energy on the environment, and on the other hand, creating incentives for the transition to environmentally friendly technologies (Chigrin and Pimonenko, 2014). Considering the fact that the current environmental tax, which is levied for various types of pollution of the environment, does not lead to significant changes in the energy sector functioning, a pricing policy may be such a tool. So, the purpose of the article is to develop an approach to electricity pricing that will allow to consider the anthropogenic impact of its production and to smooth regional imbalances.

\section{Literature review}

The scientific approaches and modern experience of the countries of the world in searching for ways to improve the efficiency of the energy sector from the economic and environmental point of view have shown the importance of the price factor in achieving the objectives of the state energy policy. In particular, the spreading of differentiated tariffs for electricity takes place mainly due to the introduction of a dynamic tariff. Saraiva et al. (2016) summarised the existing dynamic tariff schemes in a form of four groups. Real-time pricing is the most complex mechanism that provides for the dependence of the electricity pricing on its production costs. At the same time, market prices for electricity are communicated to customers in a few hours, which changes their demand.

Critical peak pricing is the establishment of maximum prices during periods of peak demand (maximum network load), which significantly exceed normal prices. A feature of the introduction of this tariff is the need to determine the period of maximum prices in advance.

Critical peak rebate is a provision of discounts when customers fulfil certain conditions for electricity use, for example, reducing demand. Direct load control is a direct control of electricity supply to certain consumers and interruption of electricity supplies in certain cases.

As you can see, the purpose of introducing these dynamic tariff schemes can be prices balance and the cost of electricity production (real-time pricing), provision of a consistent load on the network (critical peak pricing), reduction of electricity consumption by indirect (critical peak rebate) or direct methods (critical peak rebate).

However, on the other hand, the empirical calculations carried out by Holland and Mansur (2008) showed that such a form of dynamic tariff schemes as real-time pricing does not allow to reduce emissions of harmful substances, and its implementation is even associated with the growth of environmental pollution, which makes this approach open to question and requires a comprehensive analysis of the prerequisites and consequences of its introduction in a particular country.

Another problem connected with the introduction of dynamic tariffs is the need to create a positive perception of such a scheme from the point of view of electricity consumers. Results of behavioural modelling for US and EU residents show that the 
transition from fixed to dynamic tariff is largely due to the availability of enough information about the environmental and system benefits of dynamic tariff use (Buryk et al., 2015).

Another area of research is the detection of dependencies between the electricity pricing and its consumption to test the hypothesis of an increase in energy efficiency under the influence of state price regulation. In this aspect, scientists get mixed results. An analysis of long-term tendencies and forecasting of energy consumption by households in selected European countries showed growth in electricity consumption, despite the active policy of countries to save energy (Tvaronavičienè et al., 2018). Moreover, the results of analysis conducted by Shindina et al. (2018) show the absence of an inverse relation between the growth of electricity price and the volume of its consumption in European countries. Chen (2017) confirms the hypothesis that there is no significant effect of electricity pricing on consumption volumes on the example of Taiwan.

On the other hand, Kohler (2013) modelling long-run and short-run energy efficiency by electricity pricing, concludes that the introduction of differentiated tariffs for electricity can be a powerful trigger for the efficiency of electricity consumption and economic processes optimisation. Thus, the establishment of higher tariffs for energy-intensive industries results in the disadvantage of using obsolete technologies and, as a result, creates conditions for structural reorganisation of the country's economy.

In addition, the electricity pricing, as well as the cost of energy resources, are the most important statistically significant determinants of electricity supply subsequent to the results of fixed effect modelling based on 2009-2014 data (Nababan, 2016). The authors in the paper (Dado et al., 2017) made conclusion that the lower level of energy utility bills for the households compare with other EU countries restricted the spreading of alternative energy in Ukraine.

The regulation of electricity tariffs in the world also provides support for electricity production from renewable sources that in a number of European countries implemented through the introduction of feed-in tariffs, in order to stimulate the involvement of economic entities in switching to the green energy production and use. The results of analysis showed that feed-in tariff is the most popular insensitive instruments among EU (Prokopenko et al., 2017). At the same time, the support for renewable energy has long-term positive economic consequences. Thus, the study of electricity pricing dynamics in the UK shows the existence of a long-term trend to a reduction in electricity pricing and the cost of its supply, one of the reasons for which in 2000 is the growth of energy production from renewable sources (Fouquet, 2011).

Kasperowicz et al. (2017) model the impact of electricity generation by wind farms on the total price of electricity and conclude that building up the wind power plant leads to a reduction in electricity pricing in a closed energy system.

The links between electricity prices and the share of energy production from renewable sources are multilateral. Thus, the statistically significant direct effect of the cost of electricity on renewable electricity adoption (solar and small-wind stations) by US farms is confirmed by Xiarchos and Lazarus (2013).

However, as shown in the analysis conducted by Sahari (2017) at the household level, investments in the use of energy-saving technologies are sensitive to electricity prices, especially during the housing construction. The activity of households establishing heat 
pumps and solar panels depends on such factors as education, age, income level and creditability.

Kök et al. (2018) investigate the effects of different types of electricity pricing policies on investment in wind energy and solar energy production by utility firms in US. The main conclusion of the model is that flat pricing policy has more stimulating impact on investment in renewable energy production than peak pricing policy. In addition, flat pricing policy implication is related with lower carbon emissions.

Modern economic literature expands the interpretation of the harmful influence of power stations, the restriction of which should be the focus of a state policy. The growth of pollutant emissions from the energy sector not only negatively affects the ecological state of the country, but also significantly reduces the quality of social sector, worsening the indicators of human life and health (Gupta, 2017; Vasilyeva et al., 2018a). The direct negative social consequences are determined by the number of deaths during the extraction, processing, transportation and use of energy fuels, the operation of power plants, and the remote ones - by the slowed down cumulative effect (burning the energy resources, the epidemic after flooding) on the public health.

Focusing on the strategy of preserving the environment and taking into account the social consequences of the functioning of the energy sector leads to a change in the concept of determining the cost of electricity. Keske et al. (2012) calculate the cost of electricity as the sum of direct costs for its production, and social costs including environmental costs. Based on the results of calculations for various types of power plants, the optimal in terms of total social costs is the use of onshore wind as energy source.

This approach is confirmed by other empirical studies. Assessing the results of the operation of coal-fired power plants Gupta and Spears (2017), come to the conclusion that the rise of social costs (set of health indicators) significantly exceeds the regional economic benefits obtained from the expansion of the capacity of thermal power plants. In addition, the added economic benefits created by local power stations extend beyond the boundaries of a particular region, while local residents suffer from harmful social consequences.

Regional differentiation of electricity pricing also has an important economic value. He et al. (2015) proved a positive correlation between the level of electricity prices and the absolute level of economic development in different regions of China. In this case, the results of the modelling showed that electricity prices are determinants of the overall economic development of a region.

Based on preliminary results, we believe that the new approach to electricity pricing have to be based on the following assumptions:

1 Simultaneous calculation of the cost of production of electricity and environmental damage incurred in its production.

2 Implementation of the principle of social justice through compensation for anthropogenic impact in places of power generation.

3 Smoothing regional disproportions in electricity generation and consumption.

Thus, the main hypothesis of the study is that the tariff for electricity in the areas of its production should be less than in the places of its consumption. 


\section{Research methodology}

The current approach to the formation of retail electricity tariffs in Ukraine involves the inclusion of three components in the selling price:

$$
T=T P_{r}+T T_{r}+T S
$$

where $T$ is a retail tariff for electricity, $T P_{r}-$ tariff for electricity production; $T T_{r}-$ tariff for transmission of electric energy; $T S$ - tariff for the supply of electric energy to consumers.

The wholesale market price for electric energy is formed on the Wholesale market of electric energy. The mechanism of competition in the market is as follows: manufacturers offer electricity to the wholesale market at a price set on an hourly basis for each power unit of the power station (hourly application), and at which the manufacturer agrees to sell it. At the same time, the rules of the wholesale electricity market provide that the generating companies of the thermal power plants submit price applications from each unit, and the wholesale electricity market gains the necessary daily power, guided by the lowest estimated price.

In the structure of the tariff of any product, the cost of electricity is included, reflecting the cost of its production. Due to high prices for natural resources and outdated equipment, the cost of electricity produced in gas and coal power stations is higher compared to other power stations. At the same time, the cost of electricity sales is significantly different for different types of power stations. The wholesale electricity market of Ukraine buys energy at power stations working on alternative energy sources based on feed-in tariffs, while power stations that use traditional electricity sources sell it at current prices. As a result, the price of electricity sales to the wholesale market by thermal, wind and hydroelectric power stations is on average equal, while the feed-in tariff for solar power stations is almost 4 times higher than wholesale prices for other types of power stations.

Thus, the situation prevailing in the energy sector is characterised not only by excessive man-caused load, but also by the lack of economic expediency of the operation of thermal power stations.

Taking into account the direct and indirect anthropogenic impact of all types of electric power stations on the groups of recipients, we differentiate the payment for the consumed electric energy, taking into account the ratio of production and consumption volumes in order to implement the principle of social justice: some regions produce for others, live on contaminated territories and undergo additional ecological and economic losses; others live on environmentally clean areas and consume electricity produced in other regions.

Taking this into account, we propose to introduce a regional differentiation of retail electricity tariffs for consumers taking into account the ecological destructive impact of energy objects at all stages of the life cycle of the energy product, which will be calculated in the following way $\mathrm{UAH} / \mathrm{kWh}$ :

$$
T_{i t}=T_{t}+T_{t} \cdot \Delta T_{i t}
$$

where $T_{i t}$ is the estimated value of the regional electricity tariff, taking into account anthropogenic loading; $i=1, \ldots, N$ - regions, $t=1, \ldots, T$ - years; $T t$ - fixed retail electricity tariff, established by the National Commission, which performs state 
regulation in the energy and utilities sectors, $B t^{\text {th }}$ year, $\mathrm{UAH} / \mathrm{kWh}$ (depending on the type of consumer); $\Delta T_{i t}$ - is the corrective factor for the fixed retail electricity tariff for the $i^{\text {th }}$ region in $t^{\text {th }}$ year.

We propose to calculate the correction factor from the point of view of the relative level of anthropogenic loading in the region, as well as indicators of production and consumption of electricity:

$$
\Delta T_{i t}=\frac{C E_{i t}-\sum_{k=1}^{n} P E_{k_{i t}} \cdot A I_{k}^{f}}{C E_{i t}+\sum_{k=1}^{n} P E_{k_{i t}} \cdot A I_{k}^{f}}
$$

where $C E_{i t}$ is the amount of electricity consumed in the $i^{\text {th }}$ region in the $t^{\text {th }}$ year, million $\mathrm{kWh} ; P E_{k t i}-$ amount of electricity produced in the $t^{\text {th }}$ year at the $k^{\text {th }}$ power station, million $\mathrm{kWh} ; A I_{k}^{f}-$ a relative level of anthropogenic impact of the $k^{\text {th }}$ power station, belonging to $f$ type; $f$ - the type of electric station (hydroelectric power station, thermal, wind, etc.); $n$ - the number of electric stations in the $i^{\text {th }}$ region.

The level of anthropogenic loading is determined by the indicators of direct and indirect impact on the natural environment from the operation of power stations in the region:

$$
A I_{k}^{f}=\frac{E m_{d}^{d i r}+E m_{f}^{i n d i r}}{\sum E m_{f}^{d i r}+E m_{f}^{\text {indir }}}
$$

where $E m_{f}^{d i r}$ is direct emissions of harmful substances for the $f^{\text {th }}$ type of power station, $\mathrm{g} / \mathrm{kWh} ; E m_{f}^{\text {indir }}$ - indirect emissions of harmful substances for the $f^{\text {th }}$ type of power station, $\mathrm{g} / \mathrm{kWh} ; \overline{\sum E m_{f}^{d i r}+E m_{f}^{i n d i r}}$ - an average value of total volume of direct and indirect emissions of harmful substances from each $f^{\text {th }}$ type of power station, mln tons.

In accordance with the basic principles of the Kyoto Protocol and the statistical information of the International Energy Agency, the main (in terms of specific weight in aggregate volume) and the most harmful emissions are carbon dioxide emissions. Therefore, the basis for calculating $E m_{f}^{d i r}$ та $E m_{f}^{i n d i r}$ indicators is taken as permanent table values (see Table 1).

Table 1 The value of direct and indirect carbon dioxide emissions by types of power stations

\begin{tabular}{lcccc}
\hline The type of power station by the types of fuel & $E m_{f}^{\text {dir }}$ & $E m_{f}^{\text {indir }}$ & $E m_{f}^{\text {dir }}+E m_{f}^{\text {indir }}$ & $A I_{f}$ \\
\hline Coal & 1,017 & 289 & 1,306 & 3.04 \\
Gas & 575 & 113 & 688 & 1.60 \\
Water & 0 & 236 & 236 & 0.55 \\
Solar energy & 0 & 280 & 280 & 0.65 \\
Wind energy & 0 & 48 & 48 & 0.11 \\
Nuclear fuel & 0 & 21 & 21 & 0.05 \\
\hline
\end{tabular}


The average value of the sum of direct and indirect emissions for all types of energy

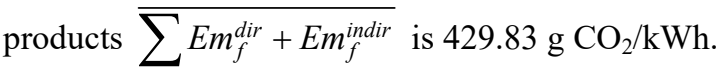

The calculations are conducted on an annual basis of 2016 for 22 regions of Ukraine, for which complete statistics are available.

\section{Results and discussion}

\subsection{Descriptive statistics}

The modern approach to regulating electricity prices provides the differentiation of retail tariffs for the consumer as a final participant in the life cycle of the energy product (see Figure 1).

Figure 1 Existing approach to differentiation of electricity tariffs in Ukraine, price with VAT in 2016, kopecks/kWh

Category of electricity consumers

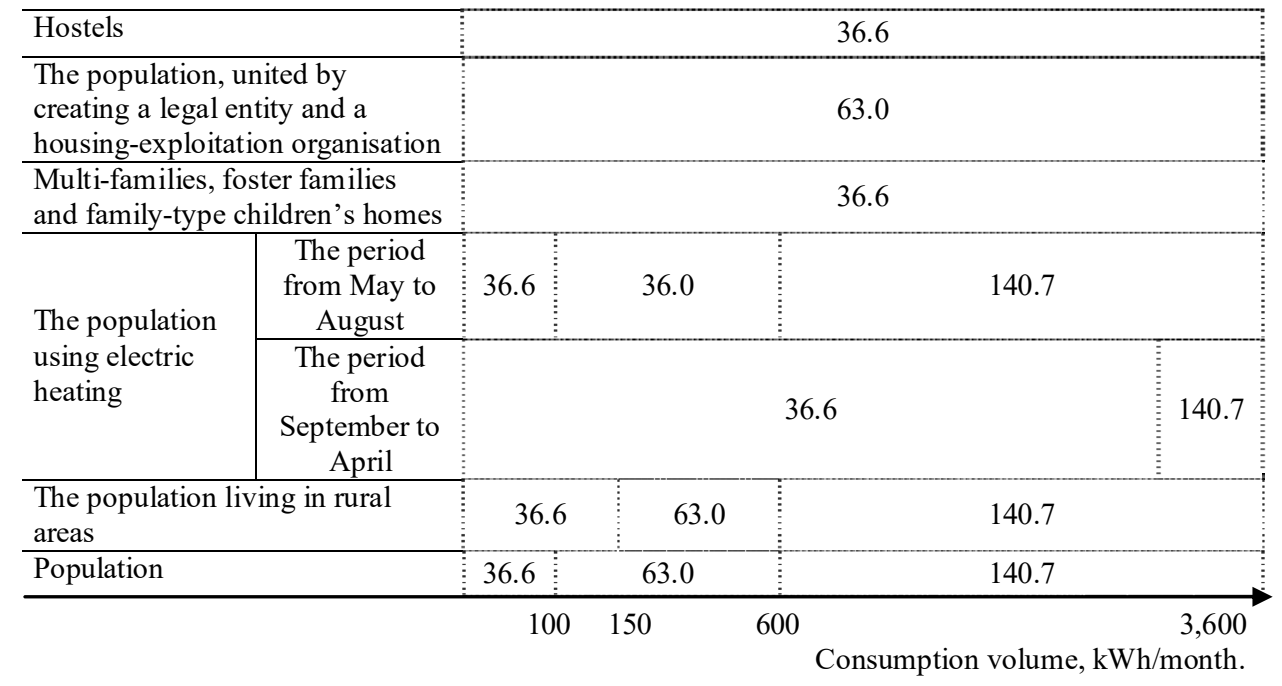

The payment for consumed electric energy is carried out depending on the volume of its consumption. There is also the differentiation of tariffs by categories of the population depending on the volume of consumption. At the same time, the electric energy generation is carried out by different types of power stations, after which the electric energy is directed to a single electrical network, from which the same energy product is consumed.

Thus, the existing system does not create incentives for electricity consumed from renewable sources, however, it has some potential to reduce energy consumption due to its economy by categories of the population for whom advanced tariffs have been set.

Regional imbalances in the location of power facilities in Ukraine are historically conditioned by natural conditions. So, hydroelectric power stations are located in the riverbeds, thermal power stations - near the places of extraction of fuel energy resources. 
At the same time, the most powerful power stations provide with the final product not only the population of this region, but also satisfy the need for electricity in the regions where there is a shortage of power capacities.

Table 2 shows the indicators of production (PE) and consumption (CE) of electric energy, as well as emissions of harmful substances (for carbon dioxide) (Em) for different regions of Ukraine.

Table 2 Volumes of production and consumption of electric energy in different regions of Ukraine in 2016

\begin{tabular}{lccc}
\hline Region & $P E$, million $\mathrm{kWh}$ & CE, million $\mathrm{kWh}$ & $\Delta(\mathrm{PE}-\mathrm{CE})$, million $\mathrm{kWh}$ \\
\hline Vinnitsa & $4,215.10$ & 675.09 & $3,540.01$ \\
Volyn & 0.00 & 312.96 & -312.96 \\
Dnipropetrovsk & $11,589.40$ & $1,749.45$ & $9,839.95$ \\
Zhytomyr & 0.00 & 419.87 & -419.87 \\
Zakarpattia & 142.60 & 695.88 & -553.28 \\
Zaporizhzhia & $51,768.60$ & 839.82 & $50,928.78$ \\
Ivano-Frankivsk & $8,897.30$ & 419.05 & $8,478.25$ \\
Kyiv & $10,311.00$ & 895.95 & $9,415.05$ \\
Kirovograd & $1,458.50$ & 411.98 & $1,046.52$ \\
Lviv & $1,990.40$ & 802.85 & $1,187.55$ \\
Mykolayiv & $18,595.70$ & 580.50 & $18,015.20$ \\
Odessa & 93.80 & $1,444.98$ & $-1,351.18$ \\
Poltava & $1,209.00$ & 554.32 & 654.68 \\
Rivne & $16,434.80$ & 351.48 & $16,083.32$ \\
Sumy & 4.00 & 403.30 & -399.30 \\
Ternopil & 0.00 & 351.56 & -351.56 \\
Kharkiv & $8,126.00$ & $1,329.81$ & $6,796.19$ \\
Kherson & $1,463.80$ & 727.90 & 735.90 \\
Khmelnytsky & $13,783.10$ & 432.98 & $13,350.12$ \\
Cherkasy & 897.90 & 532.36 & 365.54 \\
Chernivtsi & 61.20 & 484.68 & -423.48 \\
Chernihiv & 0.40 & 453.60 & -453.20 \\
\hline & & & \\
\hline
\end{tabular}

As we see, 8 out of 22 regions of Ukraine are characterised by a shortage of electricity production to meet their own needs. At the same time, there is no power station in three areas, but the population still has uninterrupted power supply. Thus, the population of Dnipropetrovsk region, on the territory of which there are two thermal power stations and a heat and power plant, consumes electric energy at the same tariff as the population of Zhytomyr region, on the territory of which there is no power station.

It is known that the most ecologically dangerous are power stations operating on fossil energy resources (thermal power stations and heat and power plants). Due to the significant coal reserves in Donbass and Prydniprovie in the last 20 years of the Soviet Union's existence, Ukraine was characterised by high growth rates of thermal power plants. Also, the main consumers of electricity are concentrated in Donbass and 
Prydniprovie - mining, metallurgy, chemical industry, mechanical engineering, etc.). This is the main reasons for the uneven territorial allocation of capacities for electricity production, energy consumption objects and, consequently, different anthropogenic pressure on the environment in the regions.

Taking into account the fact that the largest part of $\mathrm{CO}_{2}$ emissions is attributed to thermal power stations and heat and power plants, it can be said that the generation of electricity is environmentally burdensome for the inhabitants of the regions where the largest thermal power is concentrated. In total, out of the 100 largest industrial facilities in Europe, 13 are located on the territory of Ukraine (thermal power stations). A comparison of the total and 'dirty' production of electric energy (electricity production, which cause the emissions of harmful substances into the environment) on the territory of Ukraine is shown in Table 3.

Table 3 The complete and 'dirty' electric power generation and carbon dioxide emissions on regions of Ukraine in 2016

\begin{tabular}{lccc}
\hline Region & $\begin{array}{c}\text { Total power generation, } \\
\text { million } \mathrm{kWh} / \mathrm{h}\end{array}$ & $\begin{array}{c}\text { 'Dirty' generation of } \\
\text { electricity, million } \mathrm{kWh}\end{array}$ & $\begin{array}{c}\text { Emissions of carbon } \\
\text { dioxide, million tons }\end{array}$ \\
\hline Vinnitsa & $4,215.10$ & $4,020.07$ & 0.15 \\
Volyn region & 0.00 & 0.00 & 0.01 \\
Dnipropetrovsk & $11,589.40$ & $10,474.74$ & 0.94 \\
Zhytomyr & 0.00 & 0.00 & 0.02 \\
Zakarpattia & 142.60 & 142.60 & 0.01 \\
Zaporizhzhia & $51,768.60$ & $5,661.12$ & 0.25 \\
Ivano-Frankivsk & $8,897.30$ & $8,922.26$ & 0.21 \\
Kyiv & $10,311.10$ & $9,147.06$ & 0.11 \\
Kirovograd & $1,458.40$ & 28.48 & 0.02 \\
Lviv & $1,990.40$ & $1,990.40$ & 0.12 \\
Mykolayiv & $18,595.70$ & 105.86 & 0.02 \\
Odessa & 93.80 & 84.06 & 0.03 \\
Poltava & $1,209.00$ & 1145.19 & 0.07 \\
Rivne & $16,434.80$ & 0.00 & 0.01 \\
Sumy & 4.00 & 4.00 & 0.03 \\
Ternopil & 0.00 & 0.00 & 0.00 \\
Kharkiv & $8,125.90$ & $8,075.77$ & 0.21 \\
Kherson & $1,463.80$ & 117.96 & 0.01 \\
Khmelnytsky & $13,783.10$ & 0.00 & 0.02 \\
Cherkassy & 897.90 & 0.00 & 0.07 \\
Chernivtsi & 61.60 & 0.472 & 0.00 \\
Chernihiv & 0.00 & 0.00 & 0.21 \\
\hline & & & \\
\hline
\end{tabular}

In Ukraine, the two regions (Dnipropetrovsk and Zaporizhzhia) have the largest volumes of carbon dioxide emissions due to the fact that there are the most powerful thermal power plants and thermal power plants of Ukraine. Since a significant part of $\mathrm{CO}_{2}$ emissions is attributed to emissions from energy companies, it can be argued that 
emissions by region indicate emissions from power plants located in these territories. To determine the degree of compliance of the energy industry with the criteria for sustainable development, it is necessary to analyse the main categories to which we include: energy supply and efficiency of the use of fuel and energy resources; reducing the environmentally hazardous impact of energy on the atmosphere. Table 4 shows the values of individual indicators that characterise the degree of implementation of the concept of sustainable development in the power industry by regions of Ukraine as of 2016.

Table 4 The value of indicators characterising the degree of implementation of sustainable energy development in the regions of Ukraine, as of 2016

\begin{tabular}{|c|c|c|c|}
\hline Region & $\begin{array}{l}\text { The share of natural } \\
\text { gas in the total volume } \\
\text { of energy materials } \\
\text { and products of oil } \\
\text { refining, \% }\end{array}$ & $\begin{array}{l}\text { The share of emissions } \\
\text { of pollutants into the } \\
\text { atmosphere from } \\
\text { energy in the total } \\
\text { emissions from } \\
\text { stationary sources, } \%\end{array}$ & $\begin{array}{c}\text { The volume of } \\
\text { emissions of pollutants } \\
\text { into the atmosphere } \\
\text { from energy per capita, } \\
\mathrm{kg} / \text { person }\end{array}$ \\
\hline Vinnitsa & 44.63 & 80.08 & 50.07 \\
\hline Volyn region & 3.49 & 35.61 & 2.51 \\
\hline Dnipropetrovsk & 33.93 & 53.10 & 154.56 \\
\hline Zhytomyr & 1.02 & 18.01 & 2.62 \\
\hline Zakarpattia & 1.16 & 22.37 & 1.45 \\
\hline Zaporizhzhia & 79.80 & 60.59 & 70.49 \\
\hline Ivano-Frankivsk & 56.96 & 90.47 & 129.05 \\
\hline Kyiv & 29.32 & 89.04 & 67.08 \\
\hline Kirovograd & 6.28 & 20.50 & 3.48 \\
\hline Lviv & 21.17 & 45.88 & 23.77 \\
\hline Mykolayiv & 6.15 & 26.42 & 5.70 \\
\hline Odessa & 1.24 & 22.61 & 2.67 \\
\hline Poltava & 0.28 & 29.63 & 14.15 \\
\hline Rivne & 7.68 & 50.68 & 6.53 \\
\hline Sumy & 3.34 & 28.60 & 7.57 \\
\hline Ternopil & 1.23 & 10.29 & 2.00 \\
\hline Kharkiv & 31.69 & 91.19 & 66.04 \\
\hline Kherson & 2.53 & 23.35 & 1.39 \\
\hline Khmelnytsky & 11.01 & 53.09 & 6.60 \\
\hline Cherkassy & 9.47 & 48.71 & 26.72 \\
\hline Chernivtsi & 2.32 & 57.89 & 1.86 \\
\hline Chernihiv & 17.95 & 51.10 & 21.89 \\
\hline
\end{tabular}

From the data of the table it is clear that the four regions of Ukraine - Vinnytsya, Ivano-Frankivsk, Kyiv and Kharkiv regions - have the largest share of emissions of pollutants in the atmosphere from the energy sector, where the level of the indicator exceeds $80 \%$ of the total volume of emissions from stationary sources. At the same time, pollutants from the energy sector exceed $50 \%$ of the total emissions in six oblasts of 
Ukraine (Dnipropetrovsk, Zaporizhzhia, Rivne, Khmelnytsky, Chernivetska Chernihivska). Among these regions, Zaporizhzhia, Ivano-Frankivsk and Vinnitsa regions use the largest share of natural gas in electricity generation. At the same time, the maximum volumes of pollutant emissions into the atmosphere from energy per capita were recorded in Dnipropetrovsk and Ivano-Frankivsk regions - more than $100 \mathrm{~kg}$ per person per year, while the average level in the regions of Ukraine was about $37 \mathrm{~kg}$ per person. Comparing data on electricity generation and pollutant emissions into the atmosphere, note the lack of a clear dependence on the maximum level of environmental pollution from the energy sector in regions where the maximum share of electricity is produced. This testifies to another problem of the energy sector in Ukraine - the obsolete technological capacities, the functioning of which is associated simultaneously with environmental damage and economic inaccuracy.

\subsection{Calculation results}

In order to assess the uniformity of the distribution of anthropogenic load from the functioning of the energy sector by regions of Ukraine, the median values of pollutant emissions from energy per capita $(7.57 \mathrm{~kg} /$ person) and electricity consumption in the region $(580.5 \mathrm{million} \mathrm{kWh} / \mathrm{h})$ were determined. The regions of Ukraine were classified into four groups that form the matrix for the distribution of anthropogenic stress (see Figure 2). The absolute realisation of the principle of social justice implies that all regions should be subdivided into the first and third sector matrices. At the same time, the current situation shows that the volumes of anthropogenic load per capita and the extent of electricity consumption are not balanced by regions of Ukraine.

Figure 2 Comparative characteristic of the regions of Ukraine by the degree of anthropogenic loading

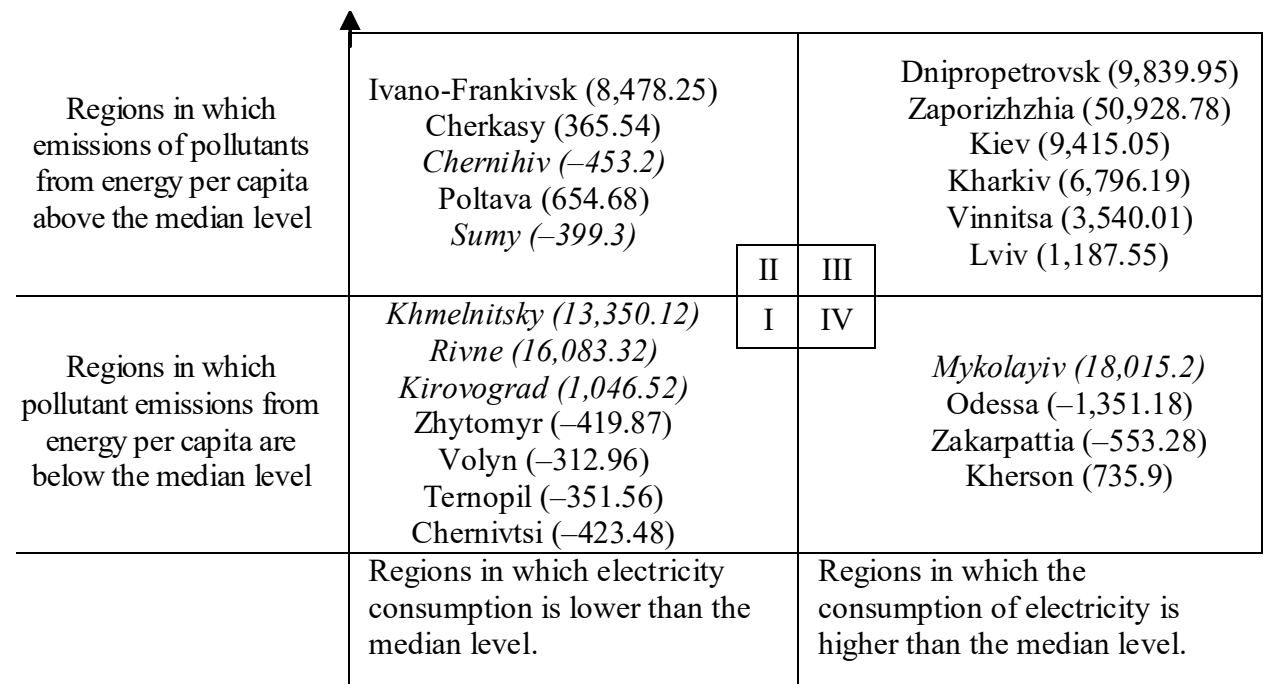

Notes: $\triangle(\mathrm{PE}-\mathrm{CE})$ is in brackets. Italicised regions with unpredicted positions in matrix.

All regions where the power of the largest thermal power plants is located are characterised by belonging to the third sector of the matrix. However, despite the high 
volume of own consumption of energy produced in the region due to the high population density and the location of industrial facilities, these regions also provide surplus production of electricity that exceeds their own needs.

The IV sector of the matrix must form industrialised densely populated regions with a shortage of energy capacities and, accordingly, use electric energy produced from other regions. However, this sector also includes the Mykolaiv region, which not only provides its own needs for electricity, but also generates its surplus, due to the presence in the region of three hydroelectric power stations and a powerful nuclear power plant, whose activities do not lead to significant pollution of the environment, as well as the Kherson region, which has a powerful hydroelectric power station.

It can be assumed that sectors with a high level of energy efficiency, which are manifested in the economical use of electricity and the production of clean energy or the use of energy produced in other regions, should come into the matrix sector. The results obtained for Ukraine make it possible to divide the regions that formed this sector into two groups. The first group is the regions with a shortage of electricity, producing a small amount of electricity (Chernivtsi region, where only one hydroelectric power station is located) or completely provide their own needs at the expense of other regions (Zhytomyr, Volyn and Ternopil regions, which do not have any power plants). Another group is formed by areas where electricity is produced from excess, in comparison with the needs of the region (Khmelnytsky and Rivne regions, where nuclear power plants are located and Kirovograd region, where a powerful hydroelectric power plant is located).

The second sector of the matrix should include regions that consume a small amount of electricity, while generating its surplus due to the significant production of 'dirty' energy. However, this group includes two areas with a lack of electricity for own production, and the excess electricity generated in other regions is insignificant compared to the region-leaders. Thus, this group can be considered the most energetically and environmentally risqué. Thus preliminary analysis showed the lack of implementation of the principle of social justice in the functioning of the energy sector in terms of anthropogenic load. It can be assumed that the use of differentiated regional influence should affect the price of electricity in almost all regions of Ukraine.

The results of calculations of retail tariffs for electric energy taking into account $\mathrm{CO}_{2}$ emissions at all stages of the life cycle of the energy product for the regions of Ukraine as of 2016 are shown in Table 5.

Table 5 Results of calculation of corrective coefficients for fixed retail electricity tariffs for regions of Ukraine by results of 2016

\begin{tabular}{lcccc}
\hline Region & CE, million $k W h$ & $C E-\sum_{k=1}^{n} P E_{k} \cdot A I_{k}^{f}$ & $C E+\sum_{k=1}^{n} P E_{k} \cdot A I_{k}^{f}$ & $\Delta T_{i t}$ \\
\hline Vinnitsa & 675.09 & $-12,013.07$ & $13,363.25$ & -0.90 \\
Volyn & 312.96 & 312.96 & 312.96 & 1.00 \\
Dnipropetrovsk & $1,749.45$ & $-10,639.17$ & $15,496.21$ & -0.69 \\
Zhytomyr & 419.87 & 419.87 & 419.87 & 1.00 \\
Zakarpattia & 695.88 & 262.50 & $1,129.26$ & 0.23 \\
Zaporizhzhia & 839.82 & $-15,317.99$ & $16,997.63$ & -0.90 \\
Ivano-Frankivsk & 419.05 & $-26,628.82$ & $27,466.89$ & -0.97 \\
Kyiv & 895.95 & $-20,888.00$ & $22,679.90$ & -0.92 \\
\hline
\end{tabular}


Table 5 Results of calculation of corrective coefficients for fixed retail electricity tariffs for regions of Ukraine by results of 2016 (continued)

\begin{tabular}{lcccc}
\hline Region & CE, million $k W h$ & $C E-\sum_{k=1}^{n} P E_{k} \cdot A I_{k}^{f}$ & $C E+\sum_{k=1}^{n} P E_{k} \cdot A I_{k}^{f}$ & $\Delta T_{i t}$ \\
\hline Kirovograd & 411.98 & -473.97 & $1,297.93$ & -0.37 \\
Lviv & 802.85 & $-5,248.05$ & $6,853.75$ & -0.77 \\
Mykolayiv & 580.50 & -735.49 & $1,896.49$ & -0.39 \\
Odessa & $1,444.98$ & $1,159.96$ & $1,730.00$ & 0.67 \\
Poltava & 554.32 & $-3,121.18$ & $4,229.82$ & -0.74 \\
Rivne & 351.48 & -470.26 & $1,173.22$ & -0.40 \\
Sumy & 403.30 & 391.17 & 415.43 & 0.94 \\
Ternopil & 351.56 & 351.56 & 351.56 & 1.00 \\
Kharkiv & $1,329.81$ & $-23,373.08$ & $26,032.70$ & -0.90 \\
Kherson & 727.90 & -410.89 & $1,866.69$ & -0.22 \\
Khmelnytsky & 432.98 & -256.18 & $1,122.14$ & -0.23 \\
Cherkassy & 532.36 & 38.53 & $1,026.19$ & 0.04 \\
Chernivtsi & 484.68 & 451.00 & 518.36 & 0.87 \\
Chernihiv & 453.60 & 453.00 & 454.20 & 1.00 \\
\hline
\end{tabular}

Negative values $\Delta T_{i t}$ testify that the production of electric energy in the given territory comes with an excess for the needs of its consumers, therefore, consumers of electric energy should receive a discount of $\Delta T_{i t}$ per unit of consumed electricity in $i$ region. The proposed regional differentiation of retail electricity tariffs allows taking into account the level of environmental degradation at all stages of the life cycle of the energy product in the mechanism of pricing for electricity. The results of the calculations have shown that the existing system for setting tariffs for electricity ensures that the principle of social justice and environmental degradation of the functioning of the energy sector is taken into account only for Cherkasy region. At the same time, other regions of Ukraine need substantial tariff adjustments to ensure a balanced development of the energy sector.

At the same time, the obtained results may be the basis for the formation of a long-term strategy for the sustainable development of the energy sector at the regional level. Thus, the regions, which are expected to increase the regional electricity tariff for the population, receive powerful economic incentives to increase their own power facilities. In turn, the regions that, due to the surplus of 'dirty' electricity generation receive a discount to the retail tariff, may accumulate part of the money released to restructure the energy sector in the direction of switching to clean energy (active strategy) or gradually reduce electricity production due to reduction of supply from the regions, who are interested in increasing their own energy production (passive strategy).

\section{Conclusions}

The requirements of the concept of sustainable development include the need to reform the energy sector, taking into account three interconnected causal links of subsystems: 
economic feasibility, environmental impact and social impacts. Theoretical and empirical studies confirm that the most effective instrument of state influence on the development of the energy sector is the pricing policy, which determines most of the parameters of its functioning. Changing the paradigm for electricity price formation involves taking into account not only its cost and related costs, but also environmental and social consequences.

For the introduction of the principle of social justice in accordance with the requirements of the sustainable development concept, electricity tariffs should be differentiated according to regions. Statistical analysis showed that the regions in which thermal power plants and thermal power plants are located are significantly more affected by anthropogenic than the regions in which heat is not concentrated capacities. The volume of electricity consumption by regions of Ukraine is much lower than the volume of its 'dirty' production (i.e., production at thermal power plants and heat plants that are the largest polluters of the environment).

The existing system of formation of retail electricity tariffs in Ukraine does not stipulate their differentiation by region or type of energy resources used. Taking into account the indices of electricity production and consumption, the structure of the energy sector and the level of anthropogenic load at the regional level, corrective factors for the retail electricity tariff were calculated. The application of this approach will allow the use of electricity pricing as a tool for regulating the development of the energy sector.

\section{Acknowledgements}

The survey was supported by the Ministry of Education and Science of Ukraine and performed the results of the project "Modeling and forecasting of the socio-economic-political road map of reforms in Ukraine for the transition to a sustainable growth model" (registration number 0118U003569).

\section{References}

Balitskiy, S., Bilan, Y., Strielkowski, W. and Štreimikiené, D. (2016) 'Energy efficiency and natural gas consumption in the context of economic development in the European Union', Renewable and Sustainable Energy Reviews, Vol. 55, pp.156-168.

Bryce, R. (2016) Energy Policies and Electricity Prices, Manhattan Institute Report 5, Cautionary Tales from the E.U. [online] https://www.manhattan-institute.org/sites/default/files/R-RB0316.pdf (accessed 8 March 2018).

Buryk, S., Mead, D., Mourato, S. and Torriti, J. (2015) 'Investigating preferences for dynamic electricity tariffs: the effect of environmental and system benefit disclosure', Energy Policy, Vol. 80, pp.190-195, DOI: 10.1016/j.enpol.2015.01.030.

Cebula, J. and Pimonenko, T. (2015) 'Comparison financing conditions of the development biogas sector in Poland and Ukraine', International Journal of Ecology and Development, Vol. 30, No. 2, pp.20-30.

Chen, Y-T. (2017) 'The factors affecting electricity consumption and the consumption characteristics in the residential sector - a case example of Taiwan', Sustainability, Vol. 9, No. 8 [online] http://www.mdpi.com/2071-1050/9/8/1484 (accessed 23 March 2018).

Chigrin, O. and Pimonenko, T. (2014) 'The ways of corporate sector firms financing for sustainability of performance', International Journal of Ecology and Development, Vol. 29, No. 3, pp.1-13. 
Chygryn, O. (2016) 'The mechanism of the resource-saving activity at joint stock companies: the theory and implementation features', International Journal of Ecology and Development, Vol. 31, No. 3, pp.42-59.

Dado, J., Pimonenko, T. and Prokopenko, O. (2017) 'Net zero house: EU experience in Ukrainian conditions', International Journal of Ecological Economics and Statistics, Vol. 38, No. 4, pp.46-57.

Dudnyk, S.V. and Koshelia, I.I. (2015) 'Health' state tendencies of population in Ukraine', Health of Nation, Ukraine, Vol. 4, No. 40, pp.67-77.

Fouquet, R. (2011) 'Divergences in long run trends in the prices of energy and energy services', Review of Environmental Economics and Policy, Vol. 5, No. 2, pp.196-218.

Gupta, A. and Spears, D. (2017) 'Health externalities of India's expansion of coal plants: evidence from a national panel of 40,000 households', Journal of Environmental Economics and Management, Vol. 86, pp.262-276, DOI: 10.1016/j.jeem.2017.04.007.

Gupta, R. (2017) 'Socioeconomic challenges and its inhabitable global illuminations', Socio Economic Challenges, Vol. 1, No. 1, pp.81-85, DOI: 10.21272/sec.2017.1-10.

He, W., Znang, C. and Hao, R. (2015) 'Analysis of electricity price policy and economic growth', Journal of Scientific \& Industrial Research, Vol. 74, No. 1, pp.11-18.

Holland, S.P. and Mansur, E.T. (2008) 'Is real-time pricing green? The environmental impacts of electricity demand variance', The Review of Economics and Statistics, Vol. 90, No. 3, pp.550-561.

International Energy Agency (2014) Key World Energy Statistics 2014 [online] http://www.iea.org/ publications/freepublications/publication/key-world2014.pdf (accessed 15 December 2017).

Kasperowicz, R. and Štreimikienè, D. (2016) 'Economic growth and energy consumption: comparative analysis of V4 and the 'old' EU countries', Journal of International Studies, Vol. 9, No. 2, pp.181-194, DOI: 10.14254/2071-8330.2016/9-2/14.

Kasperowicz, R., Pinczyński, M. and Khabdullin, A. (2017) 'Modeling the power of renewable energy sources in the context of classical electricity system transformation', Journal of International Studies, Vol. 10, No. 3, pp.264-272, DOI: 10.14254/2071-8330.2017/10-3/19.

Keske, C.M.H., Evans, S.G. and Iverson, T. (2012) 'Total cost electricity pricing: a market solution for increasingly rigorous environmental standards', The Electricity Journal, Vol. 25, No. 2, pp.7-15, DOI: 10.1016/j.tej.2012.02.004.

Kharlamova, G., Nate, S. and Chernyak, O. (2016) 'Renewable energy and security for Ukraine: challenge or smart way?', Journal of International Studies, Vol. 9, No 1, pp.88-115, DOI: $10.14254 / 2071-8330.2016 / 9-1 / 7$.

Kohler, M. (2013) Differential Electricity Pricing and Energy Efficiency in South Africa, ERSA Working Paper No. 396, Economic Research Southern Africa.

Kök, A.G., Shang, K. and Yücel, S. (2018) 'Electricity pricing and renewable energy investments', Management Science, Vol. 64, No. 1, pp.1-18.

Kouassi, K.B. (2018) 'Public spending and economic growth in developing countries: a synthesis', Financial Markets, Institutions and Risks, Vol. 2 No. 2, pp.22-30, DOI: 10.21272/ fmir.2(2).22-30.2018.

Mačerinskienė, I. and Kremer-Matyškevič I. (2017) 'Assessment of Lithuanian energy sector influence on GDP', Montenegrin Journal of Economics, Vol. 13, No. 4, pp.43-59, DOI: $10.14254 / 1800-5845 / 2017.13-4.4$.

Nababan, T.S. (2016) 'Analysis of factors affecting the electricity supply in Indonesia', in International Conference on Accounting, Management, Economics and Social Sciences (ICAMESS), pp.1-11.

Nguedie, Y.H.N. (2018) 'Corruption, investment and economic growth in developing countries: a panel smooth transition regression approach', Socio Economic Challenges, Vol. 2, No. 1, pp.63-68, DOI: $10.21272 /$ sec.2(1).63-68.2018. 
Piłatowska, M. and Włodarczyk, A. (2018) 'Decoupling economic growth from carbon dioxide emissions in the EU countries', Montenegrin Journal of Economics, Vol. 14, No. 1, pp.7-26, DOI: $10.14254 / 1800-5845 / 2018.14-1.1$.

Pilia, G. (2018) 'Estonia and Lithuania in transition: a compared analysis of the change and its costs and benefits', Business Ethics and Leadership, Vol. 1, No. 2, pp.12-19, DOI: 10.21272/ bel.1(2).12-19.2017.

Prokopenko, O., Cebula, J., Chayen, S. and Pimonenko, T. (2017) 'Wind energy in Israel, Poland and Ukraine: features and opportunities', International Journal of Ecology and Development, Vol. 32, No. 1, pp.98-107.

Ruska, M. and Kiviluoma, J. (2008) 'Renewable electricity in Europe. Current state, drivers, and scenarios for 2020', Espoo 2011, VTT Tiedotteita-Research Notes, Vol. 2584, 72pp.

Sahari, A. (2017) Electricity Prices and Consumers' Long-Term Technology Choices: Evidence from Heating Investments, VATT Working Papers 95, VATT Institute for Economic Research.

Saraiva, J.T. et al. (2016) 'Implementation of dynamic tariffs in the Portuguese electricity system - preliminary results of a cost-benefit analysis', Proceedings of the 13th International Conference on the European Energy Market (EEM), Institute of Electrical and Electronics Engineers, Inc., New York, USA, pp.1-5.

Shindina, T., Streimikis, J., Sukhareva, Y. and Nawrot, Ł. (2018) 'Social and economic properties of the energy markets', Economics and Sociology, Vol. 11, No. 2, pp.334-344, DOI: $10.14254 / 2071-789 X .2018 / 11-2 / 23$.

Sotnyk, I. (2016) 'Energy efficiency of ukrainian economy: problems and prospects of achievement with the help of ESCOs', Actual Problems of Economics, Vol. 175, No. 1, pp.192-199.

Sotnyk, I. and Kulyk, L. (2014) 'Decoupling analysis of economic growth and environmental impact in the regions of Ukraine', Economic Annals-XXI, Vols. 7-8, No. 2, pp.60-64.

Tvaronavičienè, M., Prakapienė, D., Garškaitė-Milvydienė, K., Prakapas, R. and Nawrot, Ł. (2018) 'Energy efficiency in the long-run in the selected European countries', Economics and Sociology, Vol. 11, No. 1, pp.245-254, DOI: 10.14254/2071-789X.2018/11-1/16.

Vasilyeva, T., Lyeonov, S., Adamičková, I. and Bagmet, K. (2018a) 'Institutional quality of social sector: the essence and measurements', Economics and Sociology, Vol. 11, No. 2, pp.248-262, DOI: $10.14254 / 2071-789 X .2018 / 11-2 / 17$.

Vasilyeva, T., Lyeonov, S., Lyulyov, O. and Kyrychenko, K. (2018b) 'Macroeconomic stability and its impact on the economic growth of the country', Montenegrin Journal of Economics, Vol. 14, No. 1, pp.159-170.

Vasilyeva, T.A. and Kasyanenko, V.O. (2013) 'Integral assessment of innovation potential of Ukraine's national economy: a scientific methodical approach and practical calculations', Actual Problems of Economics, Vol. 144, No. 6, pp.50-59.

Vasilyeva, T.A. and Pryymenko, S.A. (2014) 'Environmental economic assessment of energy resources in the context of Ukraine's energy security', Actual Problems of Economics, Vol. 160, No. 1, pp.252-260.

Vysochyna, A.V., Samusevych, I.V. and Tykhenko, V.S. (2015) 'The effect of tax tools in environmental management on region's financial potential', Actual Problems of Economics, Vol. 171, No. 9, pp.263-269.

Wang, J.S. and Orris, P. (2015) The Health Impacts of Energy Choices, Health Care Without Harm [online] http://www.healthyenergyinitiative.org/wp-content/uploads/2015/10/Health-Impactsof-Energy-Choices_DigitalVersion.pdf (accessed 2 April 2018).

Xiarchos, I.M. and Lazarus, W. (2013) Factors Affecting the Adoption of Wind and Solar-Power Generating Systems on U.S. Farms: Experiences at the State Level, U.S. Department of Agriculture [online] https://www.usda.gov/oce/reports/energy/WindSolar_Web_08162013.pdf (accessed 5 April 2018).

Yevdokimov, Y., Melnyk, L., Lyulyov, O., Panchenko, O. and Kubatko, V. (2018) 'Economic freedom and democracy: determinant factors in increasing macroeconomic stability', Problems and Perspectives in Management, Vol. 16, No. 2, pp.279-290. 